\title{
Evaluation of Wheat Germination for Making Gluten-Free Bread
}

\author{
Amany M. Sakr \\ Bread and Pastry Research Department, Food Technology Research Institute, Agricultural Research \\ Center, Giza, Egypt
}

Received: 10 Nov. 2020 / Accepted 20 Dec. 2020 / Publication date: 30 Dec. 2020

\begin{abstract}
This study included the germination process of the soft wheat (Triticum aestivum Giza 171). Wheat grains were soaked, germinated for seven days (at $20 \pm 2^{\circ} \mathrm{C}$ ).Also, protein fractions showed that the albumins and globulin increased until six days after that it decreased. As for the gluten, it decreased until sixth day after that it increased. The results from SDS-PAGE electrophoresis and extensogram confirmed these results. The results of chemical analysis reported that the wheat germination caused decrease in protein, wet and dry gluten, and total carbohydrates. However, ash, and crude fiber were increased after wheat germination for three and six days. Also, the mineral content of sodium, potassium, phosphorus, iron, and calcium increased after wheat germination for three and six days. Reduced-gluten wheat flour (after 6 days of germination) was used to prepare balady bread and was compared with bread made from raw wheat flour. Sensory evaluation, color measurements, and instrumental analyses of different bread were determined. Therefore, it is recommended to prepare bread from wheat germinated for six-day for celiac disease patients.
\end{abstract}

Key words: SDS-PAGE, germination, wheat flour, gluten protein, Sensory evolution, color measurements and instrumental analyses

\section{Introduction}

Wheat is a major component of most worldwide diets because of its nutritional quality, and the ability of its flour to produce a variety of tasty and satisfying foods. This is a consequence of the unique viscoelastic properties of wheat dough, which allow the entrapment of $\mathrm{CO}_{2}$ during fermentation, enabling the preparation of leavened bread and other baked products. These wheat products make substantial contributions to the dietary intake of energy and protein, and supply dietary fiber, minerals, vitamins, and phytochemicals (Rosell, 2012)

Wheat flour cannot be tolerated by those who suffering allergies to gluten. Therefore, the germination of wheat, to make wheat gluten-free, is suitable for celiac patients and other glutenintolerant individuals. Moreover, the low-gliadin flour has improved nutritional properties since its lysine content is significantly higher than that of normal flour. Conservative estimates indicate that celiac patients could safely consume 67 grams of bread per day that is made with low-gliadin flour. However, feeding trials with gluten-intolerant patients are still needed in order to determine whether or not the product can be consumed by the general celiac population, as well as the actual tolerated amount that can be safely ingested (Gil-Humanes et al., 2014).

During germination, the main storage biopolymers of cereal grains, namely carbohydrates, proteins, and lipids are hydrolyzed to lower molecular weight compounds, because of the activity of the hydrolytic enzymes, which are inactive in raw seeds (Guardianelli et al., 2019).

Celiac disease is a genetically intestinal disorder induced by proteins of wheat (gliadin), rye (secalin), and barley (hordein). The disease is fairly common; affecting approximately $1 \%$ of population in the US and in Europe (Fasano et al., 2003).Ingestion of the above-mentioned cereal proteins provokes variable symptoms in susceptible subjects and induces small-bowel mucosal damage characterized by flattening of villi, crypt hyperplasia, and substantial inflammation. Gliadin, secalin, and hordein are rich in proline and glutamine residues and thus only poorly cleaved by digestive proteolytic enzymes, even in healthy subjects (Garcia-Horsman et al., 2007).Incomplete degradation of these dietary proteins in the gastrointestinal tract leads to

Corresponding Author: Amany M. Sakr, Bread and Pastry Research Department, Food Technology Research Institute, Agricultural Research Center, Giza, Egypt.

E-mail:amaysakr2009@yahoo.com 
the appearance of peptide, of which some are toxic (de Riti et al., 1988 \& Sturgess et al., 1994) and others immunogenic (Anderson et al., 2000\& Shan et al., 2002) for celiac disease patients.

A preliminary study of Van Landschoot (2011) revealed that malting and brewing are able to reduce gluten epitopesmuch lower than the threshold of $20 \mathrm{ppm}$ for food products. Since wheat bran is characterized by a high content of bioactive compounds such as dietary fiber, minerals, and folic acid (Walter and others 2014), several studies have focused on germinated wheat bran as a source for peptidase. Indeed, it has been indicated that there is CD-specific peptidase activity in the bran of sprouted cereals (Gessendorfer et al., 2011 \& Schwalb et al., 2012).

Adrianos et al. (2017) reported that proteases from germinated cereals can significantly reduce the amounts of toxic gluten proteins or peptides. Therefore, they may be used in a variety of areas: food supplements that help the body digest gluten without allergic reactions, as well as in the production of special foods for CD patients. Ding et al. (2018) examined how germination time affected the functionality of whole-wheat flour (WWF) and enhancement of $\gamma$-aminobutyric acid (GABA) content through ultra sonication. The findings of this study demonstrated that controlled germination for 5-15 h produced WWF with improved flour functionality i.e., increased glucose content, less starch retrogradation during gelatinizing. Boukid et al. (2017) studied the effectiveness of germination on wheat protein degradation, with a specific focus on proteins involved in adverse reactions to wheat. The effects of 8 days of germination at $25^{\circ} \mathrm{C}$ did not have a significant effect on starch, lipid, and ash contents. General protein profile, as indicated by SDS-PAGE analysis, revealed that germination induced a relevant degradation in protein fraction. Regarding gluten peptides related to celiac disease, germination enabled an average reduction of $47 \%$ in peptides eliciting an adaptive immune response.

Germination is already a well-accepted process by consumers with many products made from sprouted seeds or containing limited amounts of flour from sprouted grains. Therefore, it was assessing the usefulness of germination in reducing gluten peptides associated with celiac disease, at the same time evaluating some technical features of the obtained germinated wheat (Boukid et al., 2018).

The aim of this study was to produce gluten-free wheat bread as an alternative to normal wheat bread for consumers suffering from gluten-related celiac diseases.

\section{Materials and Methods}

\section{Materials}

Wheat (Triticum aestivum L) Giza 171 variety, was provided from Field crops Institute, Agricultural Research Center, Giza, Egypt. Instant active dry yeast and sodium chloride were purchased from the local market, Cairo, Egypt and also carboxyl methyl cellulose (CMC) was purchased from El- Gomhouria Co., Egypt.

\section{Methods}

\subsection{Germination of wheat}

One kilogram of wheat grains was weighed, sorted, steeped in distilled water for $12 \mathrm{~h}$ at room temperature, and then completely drained of steep water using sieves. The drained wheat grain was then spread on a moistened jute sack and allowed to germinate at room temperature for seventh days at $20 \pm 2{ }^{\circ} \mathrm{C}$. After during germination period, tissues were collected daily up to seventh day and dried at $60 \pm 5^{\circ} \mathrm{C}$ for 48 hours.

\subsection{Milling of raw and germinated wheat}

The dried wheat germinated and raw grain were milled using Hummer mill to obtain whole meal flour according to AACC (2000). Whole meal wheat flour was sieved through a $50 \mathrm{~mm}$ sieve to obtain flour extraction rate and packed in polyethylene nylon; also, it was stored at room temperature to make gluten-free bread. 


\subsection{Determination of Chemical composition in raw and germinated wheat flour}

Chemical composition; protein, fat, crude fibers and ash content, total carbohydrates were determined in raw and germinated wheat flour according to AOAC (2010). Total carbohydrates were determined by difference.

\subsection{Determination of wet and drygluten in raw and germinated wheat flour:}

About $25 \mathrm{~g}$ of wheat flour was taken into a bowl and made a dough ball by water and put stands in water for 20-60 min at room temperature. After soaking knead the dough ball gently under running tap water until all starch matter removed and the web-like gluten network structure formed. Let allow the isolated gluten to stand in water for 1 hour, press the gluten ball in between the hands to dry as much as possible, weigh the moist gluten ball paced in a Petri plate. Transfer to oven, maintain at $100^{\circ}(24 \mathrm{hr}$.), after cooling dry weight of gluten was calculated according to AACC (1999).

\subsection{Determination of minerals content in raw and germinated wheat flour}

Minerals content $(\mathrm{Mg}, \mathrm{Na}, \mathrm{K}, \mathrm{Zn}, \mathrm{P}, \mathrm{Fe}$ and $\mathrm{Cu})$ in raw and germinated wheat flour were determined according to the method of the AOAC. (2010) using Atomic Absorption Spectrophotometer (Perkin Elmer, Model 3300). Phosphorus was determined by spectrophotometer according to the AOAC. (2010).

\subsection{Determination of protein fractions (albumin, globulin and gluten) in raw and germinated wheat flour}

Raw Wheat and germinated flour $(0.25 \mathrm{~g})$ were suspended in $2.5 \mathrm{~mL} 10 \% \mathrm{NaCl}$, stirred for 45 minutes and centrifuged at $4000 \mathrm{xg}$ for 10 minutes. The extraction was repeated three times. The combined supernatants contained albumins and globulins were analyzed along. The pellet remaining after the $\mathrm{NaCl}$ extraction was extracted with $2.5 \mathrm{~mL} 70 \%(\mathrm{v} / \mathrm{v})$ ethanol to separate gliadins. The extraction was carried out three times for 45 minutes and the obtained mixture was centrifuged at $4000 \mathrm{xg}$ for 10 minutes. The pellet remaining after the extraction of gliadins was treated with $2.5 \mathrm{~mL} 0.2 \% \mathrm{NaOH}$, stirred for 45 minutes, and centrifuged. Alkaline extraction was repeated three times. The combined supernatants were used to obtain the glutenin fraction (Karamaćet al., 2007). The gliadin and gluten infraction extracted from raw and germinated wheat flour present together gluten fractions. The protein content of every the fraction was determined by Kjeldahl method according to AOAC (2010).

\subsection{Extraction of total proteins}

About $0.1 \mathrm{~g}$ of fine powder from raw and germinated wheat flour then $400 \mu \mathrm{L}$ of Sample Buffer, $5 \mu$ of $10 \%$ SDS and $5 \mu$ l of $\beta$-mercaptoethanol was added then boiling the mixture for 5 min and was centrifuged at room temperature at $10,000 \mathrm{rpm}$ for $10 \mathrm{~min}$. The extracted protein were collected as supernatant and stored at $20^{\circ} \mathrm{C}$ according to method by Laemmli,(1970).

\subsection{SDS-PAGE electrophoresis}

Sodium dodecyl sulfate-polyacrylamide gel electrophoresis (SDS-PAGE) of total protein was performed in a discontinuous buffer system according to the method of Laemmli, (1970). Protein profiling of extracted samples during germination period (seventh day) were analyzed using $15 \%$ polyacrylamide gel. A protein marker (Protein Molecular weight marker, thermo) was loaded as standard along with samples. Gels were vidualized by staining with Coomassie brilliant blue R-250 and distained using 40\% methanol and 7\% acetic acid for overnight followed by gel scanning and photography.

\subsection{Extensogram of raw and germination wheat flour}

Extensogram tests were carried out to determine the elasticity, extensibility, proportion number and energy of raw and germinated wheat flour according to the method described in AACC (2000). 


\subsection{Bread Making}

The dough was prepared on a flour weight basis: for $300 \mathrm{~g}$ raw and germinated wheat flour for sex day, $3.6 \mathrm{~g}$ baker's yeast, $4.8 \mathrm{~g}$ table salt and $0.1 \%$ carboxyl methyl cellulose (CMC) as alternative gluten according to Wongklom et al., (2016). Ingredients were mixed in a mixture for $4 \mathrm{~min}$ and rested for $10 \mathrm{~min}$ with a plastic film cover to avoid drying. The dough was divided manually and dough pieces were rolled mechanically in a ball homogenizer. Dough pieces were placed on aluminum trays and fermented for $45 \mathrm{~min}$ at $30^{\circ} \mathrm{C}$. Dough pieces were baked in an electric convection oven. The baking process was performed at a fixed oven temperature of 400$450^{\circ} \mathrm{C}$ for 3-5 $\mathrm{min}$. After baking, bread loaves were rested for $30 \mathrm{~min}$ to cool down. The control sample was prepared from raw wheat flour to make control bread.

\subsection{Sensory evaluation of different bread}

A panel of 10 judges' research staff members of Bread and Pasta Dept. at the Food Technology Research Institute, Agricultural Research Center, Giza, Egypt evaluated the sensory characteristics of prepared bread. The assessment involved the consideration of (aroma, taste, texture, and color, using 5-point Hedonic rating scale (5-like extremely, 4.5-like very much, 4like moderately, 3.5-like slightly, 3-neither like nor dislike, 2.5-dislike slightly, 2- dislike moderately, 1.5-dislike very much, 1- dislike extremely) according to Bhat et al., (2015).

\subsection{Color of different bread}

Crust and crumb color was determined by a Chroma Meter CR-400colorimeter (Konica Minolta Sensing Inc., Japan), and expressed in a CIE- $L^{*} a^{*} b^{*}$ color scale (CIE-Lab). The CIELab color species composed by three perpendicular axes: $L^{*}, a^{*}$ and $b^{*}$. These three coordinates indicate the lightness of the color $\left(L^{*}\right.$; where $\mathrm{L}=100$ indicates white color and $\mathrm{L}=0$ black color), and its position between green and red ( $a^{*}$; where negative values indicate green and positive values indicate red), and between blue and yellow ( $b^{*}$; where negative values indicate blue and positive values indicate yellow). Two independent measurements were made to each of the three loaves to determine crust and crumb color according to Choudhury (2014).

\subsection{Instrumental analyses of different bread:}

Texture Profile Analysis (TPA) indices of different bread were determined using a Brookfield CT3 instrument (Brookfield Engineering Laboratories, Inc., MA 02346-1031, USA). The conditions of texture analyzer were provided with software, $35 \mathrm{~mm}$ diameter compression disc was used. Two cycles were applied at a constant crosshead velocity of $1 \mathrm{~mm} / \mathrm{s}$, to $30 \%$ of sample depth, and then returned. From the resulting force-time curve the values for texture attributes, hardness, resilience, cohesiveness, springiness and chewiness were calculated from TPA graphic according to Bourne (2003).

\section{Statistical analysis}

The data generated in this research were subjected to statistical analysis using one-way analysis of variance (ANOVA) and Duncan multiple range tests to compare the mean values at $\mathrm{P}<0.05$ level of significance (SAS, 2004).

\section{Results and Discussion}

\section{SDS-PAGE analysis}

Gluten is fractionated into alcohol-soluble prolamins and alcohol insoluble glutelins. The wheat prolamins, gliadins, are monomeric proteins with molecular weight ranging from 30 to $50 \mathrm{kDa}$ and can be classified into $\alpha / \beta, \gamma$, and $\omega$-type. The wheat glutelins, glutenins, can be divided into high molecular weight (HMW) glutenins with molecular weights of $66-88 \mathrm{kDa}$, and low molecular weight (LMW) glutenins with molecular weights falling in the range of the gliadin proteins, $\sim 32-45$ $\mathrm{kDa}($ Venselet al., 2014). The primary allergic proteins are prolamins of wheat grain with a relatively low molecular weight of about 30 to $80 \mathrm{kDa}$ (Van Eckert et al., 2010). Results showed that a gradual degradation of glutens started after three days and the lowest concentration was measured at the sixth 
day of germination of wheat grain with molecular weight $66-32 \mathrm{kDa}$, shown in Figure (1). Similar results were obtained with Bigiarini et al., (1995) \& Michalcová et al., (2012).

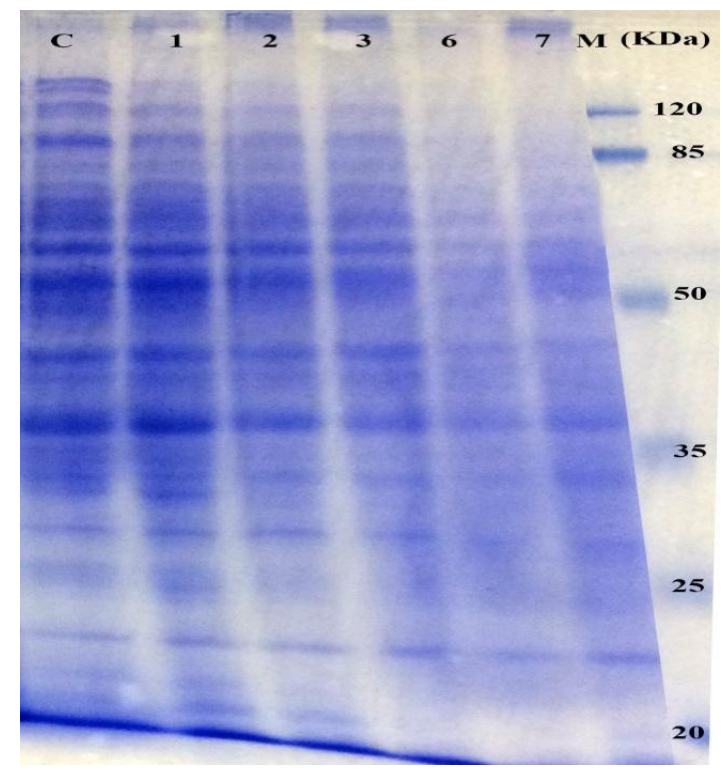

Fig. 1: SDS-PAGE analysis of gluten degradation of wheat during germination for 7 days.

During germination, besides starch, storage proteins are used to nourish the embryo. Because these proteins are insoluble in water, their utilization by the growing embryo is possible only after their degradation to soluble products (Capocchi et al., 2000). The proteolytic activity increase was due to the synthesis and secretion of endoproteases (Dominguez and Cejudo 1996). Gluten hydrolysis by endoprotease might result in an alteration of gluten epitopes immunogenic potential. According to Hartmann et al., (2006), germinated cereals led to $\alpha$-gliadin degradation into nonallergenic small peptide fragments. Later, in vitro cell trials showed that protease isolated from naturally germinating wheat did not stimulate $\mathrm{T}$-cell proliferation to the same extent as unprocessed gliadin, concluding that germinating wheat enzymes are able to alter gliadin immunological potential (Stenman et al., 2009)

Panda and Garber, (2019) indicated that the Codex Standard and the European Commission states that the gluten level of gluten-free foods must not exceed $20 \mathrm{ppm}$. The FDA requires food bearing the labeling claim "gluten-free" to contain $<20$ ppm gluten.

\section{Quantifications of protein in raw and germinated wheat}

The concentration of albumins, globulins, and gluten was determined in raw and germinated wheat and the results are reported in Table (1). From the results, it could be noticed that the albumins and globulins increased from $7.51 \mathrm{mg} / \mathrm{g}$ (dry weight) in raw wheat to $9.45,10.38$, 11.23 , and $14.75 \mathrm{mg} / \mathrm{g}$ (dry weight) in germinated wheat after one, two, three, and six days (at 20 ${ }^{\circ} \mathrm{C}$ ). Meanwhile, concentrations of these proteins decreased on the seventh day of germination (at $20^{\circ} \mathrm{C}$ ) to $12.50 \mathrm{mg} / \mathrm{g}$. This increase in concentrations of albumins and globulins may be due to the germination process of grain which is accompanied by increasing hydrolytic enzyme activities (Michalcová et al., 2012). When the hydrolytic enzyme activity was lowered after six days, albumins and globulins were increased (Mikola and Jones, 2000).

From the results in the same table, it is found that the started concentration of gluten was $32.12 \mathrm{mg} \mathrm{g}$ and after three days of germination (at $20^{\circ} \mathrm{C}$ ) the concentration decreased to 20.28 $\mathrm{mg}$ g Meanwhile, the lowest concentration of gluten was $13.19 \mathrm{mg}$ after six days of germination (at $20{ }^{\circ} \mathrm{C}$ ). These results agree with work by Koehler et al. (2007). The concentration of gluten increased after seven days of germination to be $15.38 \mathrm{mg}$. These results agree with work by Michalcová et al. (2012). These results pointed out that germination of the wheat grains until the 
sixth day is a significant tool for decreasing gluten in wheat grains, which makes it suitable for use in the production of gluten-free or gluten low loaves for celiac diseases. Wheat gluten is the viscoelastic mass that remains when starch and other water-soluble components are washed out of the wheat dough (Scherf et al., 2016). Wheat gluten consists of $>80 \%$ protein, 5-10\% lipids, and residues of starch and non-starch polysaccharides (Codex Alimentarius Standard, 2001).

Table 1: Quantifications of protein fractions in raw and germinated wheat flour (dry weight)

\begin{tabular}{lll}
\hline Treatments $\left(\mathbf{m g} / \mathbf{g}^{-\mathbf{1}}\right)$ & Albumins and globulins & Gluten \\
\hline Raw wheat & $7.51^{\mathrm{e}} \pm 0.04$ & $32.12^{\mathrm{a}} \pm 1.26$ \\
Germinated wheat after 1 day & $9.45^{\mathrm{d}} \pm 0.14$ & $29.50^{\mathrm{ab}} \pm 0.90$ \\
Germinated wheat after 2 days & $10.38^{\mathrm{c}} \pm 0.25$ & $25.24^{\mathrm{b}} \pm 1.53$ \\
Germinated wheat after 3 days & $11.23^{\mathrm{bc}} \pm 0.28$ & $20.28^{\mathrm{c}} \pm 0.92$ \\
Germinated wheat after 6 days & $14.75^{\mathrm{a}} \pm 0.39$ & $13.39^{\mathrm{e}} \pm 0.15$ \\
Germinated wheat after 7 days & $12.50^{\mathrm{b}} \pm 0.28$ & $15.38^{\mathrm{d}} \pm 0.37$ \\
\hline \multicolumn{2}{l}{ Values are means $\pm \mathrm{SD}(\mathrm{n}=3)$. Means followed by different letters in the same column are significantly } \\
\multicolumn{2}{l}{ different $(\mathrm{P} \leq 0.05)$}
\end{tabular}

\section{Chemical composition of raw and germination wheat flour}

The proximate composition of raw wheat and germinated wheat flour after 3 and 6 days are presented in Table (2). The moisture content of germinated wheat flour after 6 days was the highest $(12.80 \%)$, while that of raw wheat flour was the lowest $(12.58 \%)$. These values were within the range reported by Amagloh et al., (2012). However, investigations have shown that low moisture content of food samples is a desirable phenomenon since the microbial activity is reduced. Meanwhile, low moisture content in food samples increased the storage periods of the food products (Alozie et al., 2009), while high moisture content in foods encourages microbial growth; hence, food spoilage (Temple et al., 1996).

Moreover, the results for protein in raw and germinated wheat flour was $12.45 \%$ in raw wheat, meanwhile, in germinated wheat flour after 3 and 6 days there were a decrease to 12.11 and $11.76 \%$, respectively. Protein losses during germination have been attributed to their degradation by proteases. Furthermore, this observation agreed with other scientific findings that processing techniques such as germination improved the nutritional quality of the food products, particularly in terms of protein content (Enujiugha et al., 2003 and Fasasi, 2009).

Results showed that the highest wet and dry gluten was in raw wheat flour $25.42(10.95 \%)$. While, the wet and dry gluten in germinated wheat after three days was decreased to 22.38 $(8.13 \%)$ and the lowest gluten was that recorded after 6 germination days 18.54 (6.44\%) respectively. These results were reported by Balamurugan et al., (2018) who found that in raw wheat, the gluten ball was formed by the continuous kneading of raw wheat flour, it contain $27.52 \%$ in wet and $10.96 \%$ in dry gluten. The highest gluten content obtained after $12 \mathrm{~h}$ soaked wheat $37.4 \%$ in wet and $13.84 \%$ in dry gluten. When, after $12 \mathrm{~h}$ soaked $+24 \mathrm{~h}$ sprouted wheat, the gluten content lowered to $20.08 \%$ in wet gluten and $6.44 \%$ in dry gluten. Increased germination decreased the gluten content of wheat substantially by degrading the gliadin peptides into nontoxic fragments by proteases may benefit the gluten sensitive and celiac patients (Ali et al., 2016).

Crude fiber and ash content were increased during germination from 0.71 and $0.61 \%$ in raw wheat flour to 2.14 and $1.89 \%$ in germinated wheat after six days. Germination could be an effective way of improving the fiber content in foods (Jan et al., 2017).The increase in fiber is desirable because dietary fiber slows down glucose release from food which could be beneficial for people with diabetes. Moreover, fiber forms gels in the stomach that slows down starch digestion and gastric emptying which subsequently increase satiety (Yu et al., 2014).

Carbohydrate values and total lipids of the raw wheat flour were decreased from 84.16 and 2.07 to 82.87 and $1.34 \%$ in germinated wheat after six days, respectively. Decrease in carbohydrates in germinated grains may be attributed to increase in alph-amylase activity which breaks down complex carbohydrates into simpler and more absorbable sugars as previously reported by Hung et al., (2011).In addition, the carbohydrate and lipids contents of germinated samples were lower than that of raw wheat flour samples this observation could be due to the 
utilization of fat and carbohydrate for biochemical activities of the germinating seeds (Wang et al., 1997).

Table 2: Chemical composition of raw and germinated wheat flour on dry weight basis

\begin{tabular}{llll}
\hline Chemical Composition\% & $\begin{array}{l}\text { Raw wheat } \\
\text { flour }\end{array}$ & $\begin{array}{l}\text { Germinated wheat flour } \\
\text { After 3 days }\end{array}$ & $\begin{array}{l}\text { Germinated wheat flour } \\
\text { After 6 days }\end{array}$ \\
\hline Moisture & $12.58^{\mathrm{a}} \pm 0.84$ & $12.61^{\mathrm{a}} \pm 1.04$ & $12.80^{\mathrm{a}} \pm 1.08$ \\
Crude protein & $12.45^{\mathrm{a}} \pm 0.91$ & $12.11^{\mathrm{b}} \pm 0.95$ & $11.76^{\mathrm{c}} \pm 0.76$ \\
Wet gluten & $25.42^{\mathrm{a}} \pm 1.39$ & $22.38^{\mathrm{b}} \pm 1.57$ & $18.54^{\mathrm{c}} \pm 1.21$ \\
Dry gluten & $10.95^{\mathrm{a}} \pm 0.92$ & $8.13^{\mathrm{b}} \pm 0.84$ & $6.44^{\mathrm{c}} \pm 0.38$ \\
Total lipids & $2.07^{\mathrm{a}} \pm 0.04$ & $1.84^{\mathrm{b}} \pm 0.07$ & $1.34^{\mathrm{c}} \pm 0.08$ \\
Ash content & $0.61^{\mathrm{c}} \pm 0.02$ & $1.25^{\mathrm{b}} \pm 0.03$ & $1.89^{\mathrm{a}} \pm 0.04$ \\
Total carbohydrates & $84.16^{\mathrm{a}} \pm 3.19$ & $83.35^{\mathrm{b}} \pm 3.18$ & $82.87^{\mathrm{c}} \pm 2.97$ \\
Crude fiber & $0.71^{\mathrm{c}} \pm 0.03$ & $1.45^{\mathrm{b}} \pm 0.04$ & $2.14^{\mathrm{a}} \pm 0.09$ \\
\hline
\end{tabular}

The analytical determinations were performed in triplicate, and the means \pm Standard Deviation were reported. Means followed by different letters in the same raw are significantly different $(\mathrm{P} \leq 0.05)$

\section{Mineral content of raw and germination wheat flour}

The mineral composition of raw and germinated wheat flour (Table 3) show that the mineral composition of sodium, potassium, phosphorus, iron and calcium in raw wheat flour was $20.58,140.21,210.0,6.75$ and $18.25 \mathrm{mg} / 100 \mathrm{~g}$, respectively, on dry weight. After six-day germination recorded $50.49,220.12,240.12,8.43$ and $25.46 \mathrm{mg} / 100 \mathrm{~g}$ dry weight, respectively. Meanwhile, Magnesium, zinc and copper were significantly decreased from 12.94, 0.48 and 1.75 $\mathrm{mg} / 100 \mathrm{~g}$ dry weight in raw wheat flour to $9.56,0.16$, and $0.14 \mathrm{mg} / 100 \mathrm{~g}$ dry weight, respectively after six germination days. It was observed in this study that the germination processing techniques improved the mineral composition of the flour samples except in Magnesium, zinc and copper. This observation could be attributed to bio-synthesis and activities of microorganisms during germination processes (Gabriel and Akharaiyi, 2007).

Table 3: Mineral content in raw and germination wheat flour (on dry weight basis)

\begin{tabular}{llll}
\hline $\begin{array}{l}\text { Mineral } \\
\text { Content(mg/100g) }\end{array}$ & $\begin{array}{l}\text { Raw wheat } \\
\text { flour }\end{array}$ & $\begin{array}{l}\text { Germinated wheat flour } \\
\text { after 3 day }\end{array}$ & $\begin{array}{l}\text { Germinated wheat } \\
\text { flour after 6 day }\end{array}$ \\
\hline Magnesium & $12.94^{\mathrm{a}} \pm 0.11$ & $11.14^{\mathrm{b}} \pm 0.12$ & $9.56^{\mathrm{c}} \pm 0.29$ \\
Sodium & $20.58^{\mathrm{c}} \pm 0.43$ & $35.13^{\mathrm{b}} \pm 1.24$ & $50.49^{\mathrm{a}} \pm 1.97$ \\
Potassium & $140.21^{\mathrm{c}} \pm 3.26$ & $190.39^{\mathrm{b}} \pm 4.27$ & $220.18^{\mathrm{a}} \pm 5.31$ \\
Zinc & $0.48^{\mathrm{a}} \pm 0.04$ & $0.35^{\mathrm{b}} \pm 0.02$ & $0.16^{\mathrm{c}} \pm 0.03$ \\
Phosphorus & $210.0^{\mathrm{c}} \pm 5.13$ & $220.38^{\mathrm{b}} \pm 5.39$ & $240.12^{\mathrm{a}} \pm 6.28$ \\
Iron & $6.75^{\mathrm{c}} \pm 0.08$ & $7.51^{\mathrm{b}} \pm 0.06$ & $8.43^{\mathrm{a}} \pm 0.06$ \\
Calcium & $18.25^{\mathrm{c}} \pm 0.18$ & $20.23^{\mathrm{b}} \pm 0.27$ & $25.46^{\mathrm{a}} \pm 0.63$ \\
Copper & $1.75^{\mathrm{a}} \pm 0.01$ & $0.50^{\mathrm{b}} \pm 0.03$ & $0.14^{\mathrm{c}} \pm 0.02$ \\
\hline
\end{tabular}

The analytical determinations were performed in triplicate, and the means \pm Standard Deviation were reported. Means followed by different letters in the same raw are significantly different $(\mathrm{P} \leq 0.05)$

\section{Extensogram of raw and germinated wheat flour}

Rheologaical measurements are considered the most valuable method to assess the quality of flour; their parameters are designed to monitor the molecular structure, mechanical properties, material composition and to anticipate the quality of end product (Bockstaele et al., 2008). Extensogram represented gluten do extensibility resistance to extension, ratio of resistance to extensibility and dough deformation energy (Hadnadev et al., 2011).

Figures (2 and 3) and Table (4) showed that the extensogram test as dough extensibility significantly decreased when increasing in wheat germination time to 6 days $(50.0 \mathrm{~mm})$ compared with raw-wheat $(160.0 \mathrm{~mm})$. In addition, the raw-wheat showed a decrease in dough elasticity by 80 B.U. and elevation in germinated wheat after 6 days to 170 B.U., respectively. Singh et al., (2001) studied the effect of germinating conditions on the functional and dynamic rheological properties of wheat. They also, stated that the falling number and water absorption index (WAI) decreased and the water solubility index (WSI) increased with the increase in germination. The elastic modulus 
decreased with the increase in germination duration and also, the viscous modulus showed a decrease with the increase in germination duration.

The proportion number indicated that the ratio between the resistance to extension and extensibility were increased with the germination wheat after 6 days to 3.4 and reduction to 0.5 in raw- wheat. Finally, the energy required for deformation was decreased by the germination wheat for 6 days to $10.0 \mathrm{~cm}^{2}$ and elevated to $20 \mathrm{~cm}^{2}$ in raw- wheat.

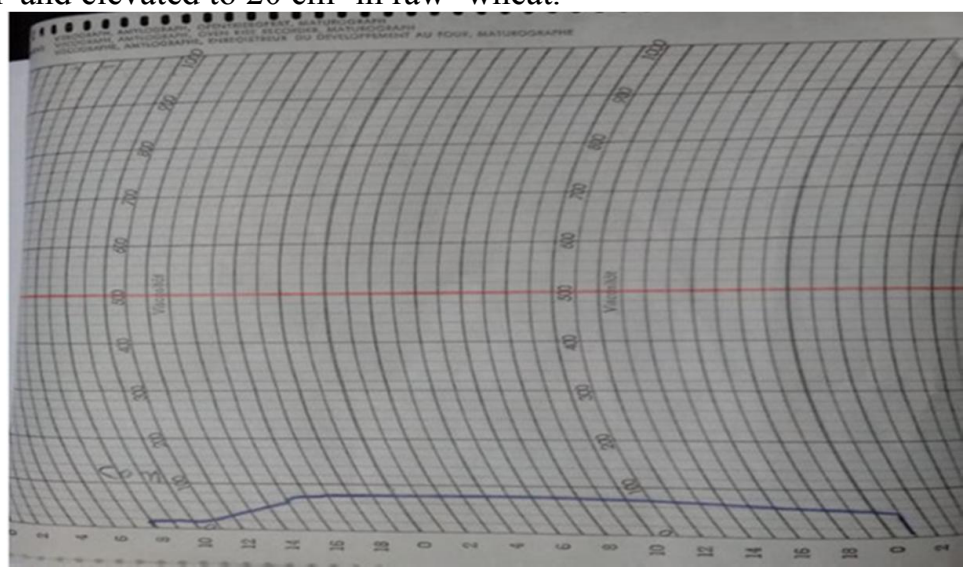

Fig. 2: Extensogram of raw wheat flour

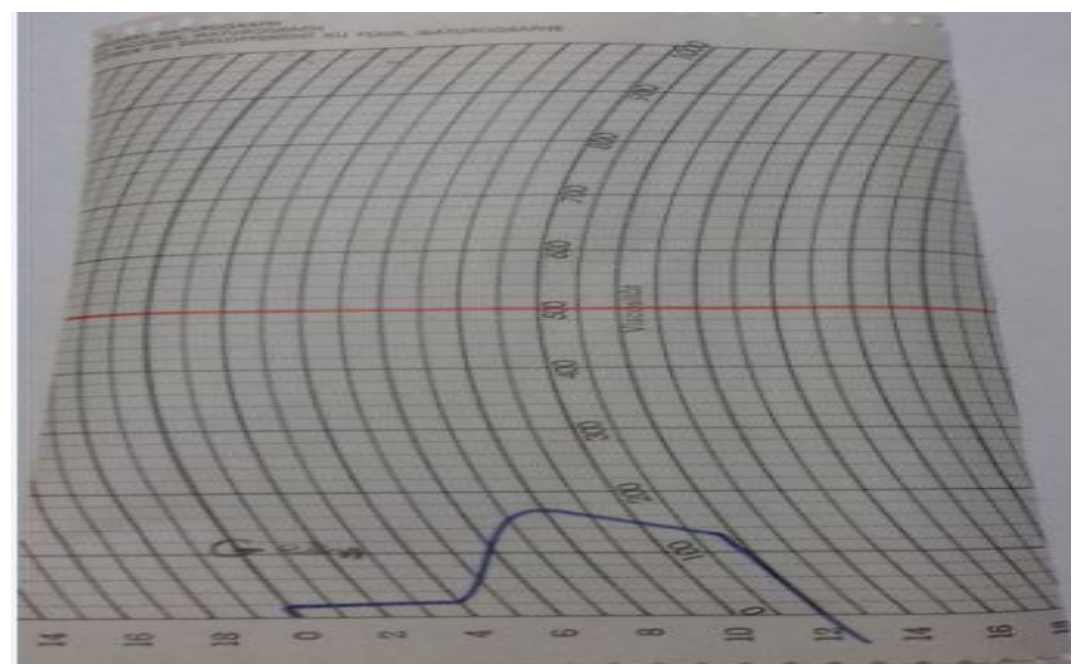

Fig. 3: Extensogram of germination wheat flour for 6 days

Table 4: Extensogram of raw and germinated wheat flour after 6 days

\begin{tabular}{lcccc}
\hline Wheat treatment & $\begin{array}{c}\text { Elasticity } \\
\text { B.U. }\end{array}$ & $\begin{array}{c}\text { Extensibility } \\
\mathbf{m m}\end{array}$ & $\begin{array}{c}\text { Proportion } \\
\text { number }\end{array}$ & $\begin{array}{c}\text { Energy } \\
\mathbf{c m}^{\mathbf{2}}\end{array}$ \\
\hline $\begin{array}{l}\text { Raw wheat flour } \\
\text { Germination wheat flour } \\
\text { after 6 day }\end{array}$ & 80.0 & 160.0 & 0.5 & 20.0 \\
& 170.0 & 50.0 & 3.4 & 10.0 \\
\hline
\end{tabular}

\section{Sensory evaluation of bread made from raw and germination wheat flour}

The assessment of bread made from raw and germinated wheat flour after 3 and 6 days involves aroma, taste, texture, and color, using 5-point Hedonic rating scale and the finding are indicated in Table (5).The results showed that the taste and aroma were decreased from 4.5 in bread made from raw wheat flour to 3.0 in bread prepared from germinated wheat flour for 6 days. Thus, this difference in taste and aroma may be attributed to the reduction of gluten during germination of wheat flour resulting in lowering down the taste and odor values (Zubaidi, 2009).

The results for color in raw and germinated wheat flour were parallel to the above results and this different color may be due to the increase in the sugar content in germinated wheat after 
6 days resulting in non-enzymatic browning during the baking process. Fadel and $\mathrm{Al}-$ Mudhafar, (2020) found that the difference between raw and germinated wheat is in color, as the color of the germinated wheat flour gives a darker color than the raw wheat flour. This is due to the drying process that takes place after the wheat germination process ending.

As for the texture the bread from raw wheat flour was superior to the bread made from germinated wheat; this was due to the high fiber content of the germinated wheat flour which led to water retention and reduction in its evaporation rate. Thereby, not allowing the pulp cells to expand, causing tissue values to be reduced (Solaka and ZainAlAbidin, 1995). Moreover, the decreases in the mean values of texture may be due to an increase in the fiber and sugar content may be able to be resulting in the hard crust.

While the changes that occur during germination can improve then nutritional value of the resulting flour, they may lower the mixing and baking (end-use) properties of flour due to increased amylolytic and proteolytic activities (Baranzelli et al., 2018). This can result in an increase in dough stickiness, difficulty in dough handling, and a decrease in dough strength (Olaerts et al., 2018).Furthermore, bread made from extensively sprouted flour resulted in sticky and gummy crumbs and poor texture (Olaerts et al., 2018).

Table 5: Sensory properties of bread made from raw and germinated wheat flour

\begin{tabular}{lllll}
\hline Treatments & Taste & Aroma & Texture & Color \\
\hline Control (raw wheat) & $4.5^{\mathrm{a}} \pm 0.14$ & $4.5^{\mathrm{a}} \pm 0.11$ & $4.5^{\mathrm{a}} \pm 0.21$ & $4.5^{\mathrm{a}} \pm 0.23$ \\
Bread after 3days & $3.5^{\mathrm{b}} \pm 0.18$ & $3.5^{\mathrm{b}} \pm 0.14$ & $3.5^{\mathrm{b}} \pm 0.09$ & $3.5^{\mathrm{b}} \pm 0.08$ \\
Bread after 6days & $3.0^{\mathrm{c}} \pm 0.13$ & $3.0^{\mathrm{c}} \pm 0.12$ & $3.0^{\mathrm{c}} \pm 0.24$ & $3.0^{\mathrm{c}} \pm 0.07$ \\
\hline
\end{tabular}

Values are means $\pm \mathrm{SD}(\mathrm{n}=3)$. Means followed by different letters in the same column, significantly different $(\mathrm{P} \leq 0.05)$

\section{Color analysis of bread made from raw and germinated wheat flour}

The $L^{*}, a^{*}$ and $b^{*}$ values of bread made from raw wheat flour as control, comported with treatment bread made from germinated wheat flour after three and six days of germination (Table 6) show that the brightness results $\left(L^{*}\right)$ showed the highest values for the control flour, which corresponded to lighter flour, whereas the bread made from germinated wheat flour after six days had the lowest value due to the reduction of gluten and brown coloring was dependent on the rate of Millard reaction, and which depend on the quality and quantity of reducing sugars and the presence of amino groups residual free in dough and the baking temperature (Fenemma, 1999). In relation to the chromaticity coordinate $a^{*}$, it was observed that the bread made from germinated wheat flour after six days had the highest value tending to a red hue. The induce germination caused an increase in $a^{*}$ value. The high $a^{*}$ values are associated with the decrease in $L^{*}$ that causes browning, as occurred in bread made from germinated wheat flour after six days. The germination did not cause changes in the $b^{*}$ values, with the exception of bread made from germinated wheat flour after six-day treatment. According to Ohm et al., (2008), the flours that have the higher water absorption and higher fiber content is less bright and redder, which explains what happened in pre-harvest sprouting flour, according to the values found for water absorption.

Table 6: Color analysis of bread made from raw and germinated wheat flour

\begin{tabular}{llll}
\hline Treatments & $\boldsymbol{L}^{*}$ & $\boldsymbol{a}^{*}$ & $\boldsymbol{b}^{*}$ \\
\hline Control raw wheat & $84.23^{\mathrm{a}} \pm 1.84$ & $1.12^{\mathrm{c}} \pm 0.02$ & $17.5^{\mathrm{a}} \pm 0.25$ \\
Bread after 3days & $80.48^{\mathrm{b}} \pm 2.04$ & $1.51^{\mathrm{b}} \pm 0.01$ & $17.0^{\mathrm{b}} \pm 0.46$ \\
Bread after 6days & $75.25^{\mathrm{c}} \pm 1.65$ & $2.32^{\mathrm{a}} \pm 0.02$ & $16.35^{\mathrm{c}} \pm 0.39$ \\
\hline
\end{tabular}

Values are means \pm SD $(n=3)$. Means followed by different letters in the same row, significantly different $(\mathrm{P} \leq 0.05)$

\section{Texture profile analysis for bread}

The results from Table (7) showed that the effect of germination of wheat on bread texture profile analysis. From the results, it could be noticed that the hardness was between 1.54 and 2 . $35 \mathrm{~N}$ from bread made from germinated wheat, this could be due to the high fiber content of the germinated wheat flour, which led to water retention and reduced its evaporation rate, thereby, causing tissue values to be reduced (Solaka and Zain Al Abidin, 1995). Meanwhile, resilience 
and cohesiveness were decreased from 0.56 and 1.12 in raw wheat bread to 0.32 and 0.80 in bread prepared from wheat germinated for six days. The reduction of resilience value during germination may be attributed to a decrease in protein and increases in crude fiber (Bhol and Bosco, 2014).As well as, springiness was decreased from 5.12 to $3.38 \mathrm{~mm}$, respectively. Meanwhile, chewiness was increased from $4.38 \mathrm{mj}$ in control raw wheat bread to $6.83 \mathrm{mj}$ in bread prepared from wheat germinated for six days, this resulted from the bread from germinated wheat had increased in hardness due to reduction of gluten and increased in natural fibrous (Kumar and Kumar, 2011).

Table 7: Texture profile characteristics of different bread

\begin{tabular}{|c|c|c|c|c|c|}
\hline Treatments & $\begin{array}{l}\text { Hardness } \\
\text { (N) }\end{array}$ & Resilience & Cohesiveness & $\begin{array}{l}\text { Springiness } \\
\text { (mm) }\end{array}$ & $\begin{array}{l}\text { Chewiness } \\
\text { (mj) }\end{array}$ \\
\hline Control raw wheat & $1.23^{c} \pm 0.01$ & $0.56^{\mathrm{a}} \pm 0.01$ & $1.12^{\mathrm{a}} \pm 0.04^{2}$ & $5.12^{\mathrm{a}} \pm 0.02$ & $4.38^{c} \pm 0.15$ \\
\hline Bread after 3days & $1.54^{\mathrm{b}} \pm 0.02$ & $0.40^{b} \pm 0.01$ & $0.90^{b} \pm 0.04$ & $4.16^{b} \pm 0.01$ & $5.89^{\mathrm{b}} \pm 0.31$ \\
\hline Bread after 6days & $2.35^{\mathrm{a}} \pm 0.01$ & $0.32^{\mathrm{c}} \pm 0.00^{2}$ & $0.80^{\mathrm{c}} \pm 0.03$ & $3.38^{\mathrm{c}} \pm 0.01$ & $6.83^{\mathrm{a}} \pm 0.42$ \\
\hline
\end{tabular}

Conclusion

The process of germinating wheat has the ability to degrade gluten interestingly, the hydrolysis of the gluten started after the three days of germination of wheat grains and the lowest concentration of protein (wet and dry gluten) and insoluble dietary fiber were achieved on the six days of wheat germinated grains. Meanwhile soluble dietary fiber and mineral contents were increased at the end period of wheat germination. Sensory evaluation, color measurement and texture analysis profile in bread made from the germinated wheat flour confirmed the reduction of gluten. Therefore, it could be used to making bread for celiac diseases.

\section{References}

AACC, 1999. Method-Wet gluten content in wheat flour by hand washing method.1999; 38$10: 1$.

AACC, 2000.American Association of Cereal Chemists. Approved method of the A.A.C.C. $10^{\text {th }}$ ed. Association of Cereal Chemists, st., Paul, Minnesota, USA

Ali, A.M., A.E. Afify, Abbas, M.S., Bothyna, and A. Lattefi, 2016. Chemical, Rheological and properties of Germinated wheat and Naked Barley. International Journal of Chemical Technology and Research, 9: 521- 531.

Alozie, Y.E., M.A. Iyam, O. Lawal, U. Udofia, I.F. Ani, 2009. Utilization of Bambara ground flour blends in bread production. J. Food Technol., 7(4):111-114.

Amagloh, F.K., J.L. Weber, L. Brough, A. Hardacre, A.N. Mutukumira, and J. Coad, 2012. Complementary food blends and malnutrition among infants in Ghana: A review and a proposed solution Sci. Res. Essays. 7(9):972-988,

Anderson, R.P., P. Degano, A.J. Godkin, D.P. Jewell, and A.V. Hill, 2000. In vivo antigen challenge in celiac disease identifies a single transglutaminase-modified peptide as the dominant A- gliadin T-cell epitope. Nat Med., 6:337-42.

Adrianos, S.L., Mattioni, B. and Tilley, M. 2017. Confirmation of gluten-free status of wheatgrass (Triticum aestivum). Quality Assurance and Safety of Crops \& Foods, 9(1), 123-128.

AOAC, 2010. Official Methods of Analysis of Association of Official Chemists.18th Ed., Washington, D.C., USA.

Balamurugan, V.S., S. Sivabalan, and I. Thamizhselvan, 2018. Determination of Gluten Level on Traditionally Treated Wheat, International Journal of Research and Analytical Reviews, 5(3):426-431

Baranzelli, J., D.H. Kringel, R. Colussi, F.F. Paiva, B.C. Aranha, M.Z. de Miranda, da Rosa E. Zavareze, and A.R.G. Dias, 2018. Changes in enzymatic activity, technological quality and gamma-aminobutyric acid (GABA) content of wheat flour as affected by germination. Lebensm.Wiss. Technol., 90: 483-490. 
Bhat, J., S. Afzal, A. Gull, H. Raees-ul and T.A. Safapuri, 2015. Textural and Sensory Characteristics of Bread Made from Wheat Flour Supplemented with Water Chestnut, American Journal of Food Science and Nutrition Research, 2(3): 94-97

Bhol, S. and S.J.D. Bosco, 2014. Influence of malted finger millet and red kidney bean flour on quality characteristics of developed bread. LWT Food Sci Technol., 55(1):294-300

Bigiarini, L., N. Pieri, I. Grilli, L. Galleschi, A. Capocchi, and D. Fontanini, 1995. Hydrolysis of gliadin during germination of wheat seeds. Journal of plant physiology, 147(2): 161-167.

Bockstaele, F.V., I. De Leyn, Eeckhout, M. and K. Dewettinck, 2008. Rheological properties of wheat flour dough and the relationship with bread volume. i. creep-recovery measurements. Cereal Chem., 85: $753-761$

Boukid, F., Prandi, B., Buhler,S. and Sforza, S. 2017. Effectiveness of germination on protein hydrolysis as a way to reduce adverse reactions to wheat, J. Agric. Food Chem., 65(45): 98549859

Boukid, F., Prandi, B., Vittadini' E., Francia, E. and Sforza, S. (2018). Tracking celiac diseasetriggering peptides and whole wheat flour quality as function of germination kinetics, Food Research International, 112, 345-352

Bourne, M. C. 2003. Food texture and viscosity: Concept and measurement. Elsevier Press, New York/ London

Capocchi, A., M. Cinollo, L. Galleschi, F. Saviozzi, L. Calucci, C. Pinzino, and M. Zandomeneghi, 2000. Degradation of gluten by proteases from dry and germinating wheat (Triticum durum) seeds: an in vitro approach to storage protein mobilization. J. Agric. Food Chem., 48: 6271-9.

Choudhury, AKR. 2014. Principle of color and appearance measurement: object appearance, color perception and instrument measurement. UK: Wood head Publishing Limited; 2014.

Codex Alimentarius Standard, 2001. Wheat Protein Products Including Wheat Gluten: CODEX STAN 163-1987, Rev.1-2001; FAO/WHO Joint Publications: Rome, Italy.

de Ritis, G., S. Auricchio, H.W. Jones, and E.J. Lew, 1988. Bernardin JE and Kasarda DD. (1988). Invitro (organ culture) studies of the toxicity of specific A-gliadin peptides in celiac disease. Gastroenterology, 94(1):41-9.

Ding, J., Hou, G.G., Nemzer, B.V., Xiong, S., Dubat, A. and Feng, H. 2018. Effects of controlled germination on selected physicochemical and functional properties of whole-wheat flour and enhanced $\gamma$-aminobutyric acid accumulation by ultrasonication. Food Chemistry, 243, 214-221.

Dominguez, F., and FJ. Cejudo, 1996. Characterization of the endoproteases appearing during wheat grain development. Plant Physiol., 112: 1211-7.

Enujiugha, V.N., A.A. Badejo, S.O. Iyiola, and M.O. Oluwamukomi, 2003. Effect of germination on the nutritional and functional properties of African oil bean (Pentaclethramacrophylla Benth) seed flour. Food Agric. Environ., 1:72-75.

Fadel, F.A. and A.W.H. Al - Mudhafar, 2020. Study of rheological and sensory properties of soft wheat (Triticum aestivum) and germinated products, Plant Archives, 20 (1): 22912296.

Fasano, A., I. Berti, T. Gerarduzzi, T. Not, R.B. Colletti, and S. Drago, 2003. Prevalence of celiac disease in at-risk and not-at-risk groups in the United States: a large multicenter study. Arch Intern Med., 163:286-92.

Fasasi, O.S., 2009. Proximate antinutritional factors and functionalproperties of processed pearl millet (Pennisetum glaucum). J. Food Technol.,7(3):92-97.

Fenemma, O.R., 1999. Food chemistry, $3^{\text {rd }}$ ed., edited by Owen R. Fennema. University of University of Wisconsin-. Madison. Wisconsin (Department of Food science and technology) page 11, Marcel Dekker, Inc. 270 Madison Avenue, New York, New York 10016

Gabriel, R.A.O. and F.C. Akharaiyi, 2007. Effect of spontaneous fermentationon the chemical composition of thermally treated jack beans (Canavalia ensiformis L.). Int. J. Biol. Chem., 1(2):91-97.

Garcia-Horsman, J.A., J.I. Venalainen, O. Lohi, I.S. Auriola, I.R. Korponay-Szabo, and K. Kaukinen, 2007. Deficient activity of mammalian prolyloligopeptidase on the immunoactive peptide digestion in coeliac disease. Scand J Gastroenterol., 42: 562-71 
Gessendorfer, B., Hartmann, G., Wieser, H. and Koehler, P. 2011. Determination of celiac diseasespecific peptidase activity of germinated cereals. European Food Research and Technology, 232(2),205-209.

Gil-Humanes, J., F. Pistón, R. Altamirano-Fortoul, A. Real, I. Comino, C. Sousa, CM. Rosell, and F. Barro, 2014. Reduced-Gliadin Wheat Bread: An Alternative to the Gluten-Free Diet forConsumers Suffering Gluten-Related Pathologies, PLoS ONE 9(3): e90898. doi:10.1371/journal.pone.0090898

Guardianelli, L.M., M.V. Salinas, and M.C. Puppo, 2019. Hydration and rheological properties of amaranth-wheat flour dough: Influence of germination of amaranth seeds. Food Hydrocoll. 97(7): 1-26.

Hadnadev, T.D., M. Pojić, H. Hadnadev, and A. Torbica, 2011. The role of empirical rheology in flour quality control. In: Wide Spectra of Quality Control. Akyar, S. (Ed.). Published by In Tech.,Pp. $335-360$.

Hartmann G, P. Koehler and H. Wieser, 2006. Rapid degradation of gliadin peptides toxic for coeliac disease patients by proteases from germinating cereals. J. Cereal. Sci. 44: 368-71.

Hung P.V., M. Tomoko, Y. Syota and M. Naofumi, 2011. Effects of germination on nutritional composition of waxy wheat. J. Sci. Food Agric., 92: 667-672.

Jan, R., D.C. Saxena, and S. Singh, 2017. Physico-chemical textural, sensory and antioxidant characteristics of gluten e Free cookies madefrom raw and germinated Chenopodium (Chenopodium album) flour. LWT - Food Science and Technology, 71: 281-287.

Karamać, M., E. Sendrejová, A. Kosińska, and D. Urminská, 2007. Presence of ferulic acid in wheat glutenin fraction and its enzymatic hydrolysates - a short report.In Czech Journal of Food Sciences, 25: 359-364.

Kumar, N. and Kumar, K., 2011. Development of carrot pomace and wheat flour based cookies.

Journal of pure and applied science and technology, 1: 5-11

Laemmli, U.K., 1970. Cleavage of structural proteins during the assembly of the head of bacteriophage T4.In Nature, 227: 680-685.

Michalcová, E., E. Potocká, D. Chmelová, and M. Ondrejovič, 2012. Study of wheat protein degradation during germination. Journal of Microbiology, Biotechnology and Food Sciences, 1(6):1439-1449.

Mikola, M. and B.L. Jones, 2000. Electrophoretic and 'in solution' analyses of endoproteinases extracted from germinated oats. In Journal of Cereal Science, 30: 227-235.

Ohm, J. B., A.S. Ross, C.J. Peterson, and Y.L. Ong, 2008. Relationships of high molecular weight glutenin subunit composition and molecular weight distribution of wheat flour protein with water absorption and color characteristics of noodle dough. Cereal Chemistry, 85: 123-131.

Olaerts, H., L. Vandekerckhove, and C.M. Courtin, 2018. A closer look at the bread making process and the quality of bread as a function of the degree of preharvest sprouting of wheat (Triticum aestivum). J. Cereal. Sci., 80: 188-197

Panda, R. and E.A.E. Garber, 2019. Detection and quantitation of gluten in fermentedhydrolyzed foods by antibody-based methods: challenges, progress, and a potential path forward, Frontiers in Nutrition, 6 (97):1-13.

Rosell, C.M., 2012. The nutritional enhancement of wheat flour. In: Improving quality, : Cauvain S, editor. Breadmaking, second edition. Sawston, Cambridge, UK: Woodhead Publishing, 687-710.

SAS, 2004. Statistical Analysis System. SAS User's Statistics SAS Institute Inc. Editors, Cary, NC.

Scherf, K.A., P. Koehler, and H. Wieser, 2016. Gluten and wheat sensitivities-An overview. J. Cereal Sci., 67: 2-11.

Schwalb, T., Wieser, H., Koehler, P. 2012. Studies on the gluten-specific peptidase activity of germinated grains from different cereal species and cultivars. European Food Research andTechnology, 235(6), 1161-1170.

Shan, L., O. Molberg, I. Parrot, F. Hausch, F. Filiz, and G.M. Gray, 2002. Structural basis for gluten intolerance in celiac sprue. Science., 297: 2275-9. 
Singh, H., N. Singh, L.K. Thapar, and S.K. Saxena, 2001. Effect of sprouting conditions on functional and dynamic rheological properties of wheat. Journal of Food Engineering, 47(1):23- 29

Solaka, A.B. and M.W. Zain El Abidine, 1995. Effect of some dietary glues on the rheological characteristics of wheat flour and bread quality. Journal of Mesopotamia Cultivation, 27(2): 50- 55.

Stenman, S.M., JI. Ven“al"ainen, K. Lindfors, S. Auriola, T. Mauriala, A. Kaukovirta-Norja, A. Jantunen, K. Laurila, S.W. Qiao, and L.M. Sollid, 2009. Enzymatic detoxification of gluten by germinating wheat proteases: implications for new treatment of celiac disease. Ann Med., 41: 390-400.

Sturgess, R., P. Day, H.J. Ellis, K.E. Lundin, H.A. Gjertsen, and M. Kontakou, 1994. Wheat peptide challenge in celiac disease. Lancet., 343: 758-61.

Temple, V.J., E.J. Badamosi, O. Ladeji, and M. Solomon, 1996. Proximatechemical composition of three locally formulated complementaryfoods. West Afr. J. Biol.Sci., 5:134-143.

Van Eckert, R., J. Bond, P. Rawson, C.H.L. Klein, M. Stern, and T.W. Jordan, 2010. Reactivity of gluten detecting monoclonal antibodies to a gliadin referencematerial. Cereal Chemistry, 51:198-204

Van Landschoot, A. 2011. Gluten-free barley malt beers. Cerevisia 36:93-7.

Vensel, W.H., C.K. Tanaka, and S.B. Altenbach, 2014. Protein composition of wheat gluten polymer fractions determined by quantitative two-dimensional gel electrophoresis and tandem mass spectrometry. Proteome Sci., $12(: 8)$ 1-13

Wang, N., M.J. Lewis, J.G. Brennan, and A. Westby, 1997. Effect of processing methods on nutrients and antinutritional factors in cowpea. Food Chem., 58:59-68.

Wongklom, P., P. Chueamchaitrakun, and N. Punbusayakul, 2016. Effect of xanthan gum/CMC on bread quality made from Hom Nil rice flour, International Food Research Journal, 23(5): 2300- 2305.

Yu, K., M.Y. Ke, W.H. Li, S.Q. Zhang, and X.C. Fang, 2014. The impact of soluble dietary fibre on gastric emptying, postprandial blood glucose and insulin in patients with type 2 diabetes. Asia Pacific Journal of Clinical Nutrition, 23: 210-218.

Zubaidi, A.H.H., 2009. Practical book in grain processing. Ministry of Higher Education and Scientific Research - University of Baghdad - College of Agriculture.University House for Printing and Publishing. 